\title{
ANALISA KEBUTUHAN PENGEMBANGAN MODEL SYSTEM BARTER DI ERA PANDEMIK COVID-19 BERBASIS WEBSITE
}

\author{
Edwin Ariesto Umbu Malahina ${ }^{1}$, Agustina Clarissa Huko Langoday ${ }^{2}$ \\ ${ }^{1}$ Program Studi Teknik Informatika D3, STIKOM Uyelindo Kupang \\ ${ }^{2}$ Program Sistem Informasi S1, STIKOM Uyelindo Kupang \\ 12 Jl. Perintis kemerdekaan I - Kel.Kayu Putih, Kec.Oebobo, Kota Kupang - NTT \\ edwinariesto@gmail.com, clarisahuko@gmail.com
}

\begin{abstract}
Barter is an exchange of needs in the form of goods to meet the necessities of life without relying on the financial side first. During the Covid-19 pandemic, many people experienced economic pressure from various problem factors, where people still have to make ends meet during the pendemic period. The purpose of this study is to be able to collect information data whether this system can help meet the needs of the community or not by using the Systems Development Life Cycle (SDLC) system development model as well as quantitative and qualitative approaches by collecting information and distributing questionnaires using the Likert scale method. The barter system that will be developed is website-based, where previously going through the process of analysis and system design first. From the results of the questionnaire calculations obtained, it was found that about an average of $85.93 \%$ of the public strongly agreed that this barter system could be developed.
\end{abstract}

Keywords - barter system, covid-19, Likert scale, Systems Development Life Cycle (SDLC), website.

\begin{abstract}
Abstrak - Barter merupakan pertukaran kebutuhan dalam dalam bentuk barang untuk memenuhi kebutuhan hidup tanpa mengandalkan sisi keuangan terlebih dahulu. Dimasa pandemic covid-19 banyak masyarakat mengalami himpitan ekonomi dari berbagai faktor masalah, dimana masyarakat tetap harus memenuhi kebutuhan hidup selama masa pendemik berlangsung. Tujuan penelitian ini adalah dapat mengumpulkan data informasi apakah system ini dapat membantu dalam memenuhi kebutuhan masyarakat atau tidak dengan menggunakan model pengembangan sistem Systems Development Life Cycle (SDLC) serta pendekatan kuantitatif dan kualitatif yang melalui pengumpulan informasi dan penyebaran kuesioner dengan menggunakan metode skala likert. System barter yang akan dikembangkan adalah berbasis website, dimana sebelumnya akan melalui proses Analisa dan perancangan system terlebih dahulu. Dari hasil kalkulasi kuesioner yang didapatkan, diperoleh bahwa sekitar rata-rata $85,93 \%$ masyarakat sangat setuju system barter ini dapat dikembangkan.
\end{abstract}

Kata Kunci - system barter, covid-19, skala likert, Systems Development Life Cycle (SDLC), website.

\section{PENDAHULUAN}

Metode barter adalah sebuah sistem transaksi pertukaran antara barang dengan barang, barang dengan jasa ataupun sebaliknya [1]. Transaksi barter pada zaman sekarang ini sudah dianggap kuno karena telah lama ditinggalkan oleh masyarakat yang sudah terbiasa melakukan transaksi dengan menggunakan uang. Namun, pada tahun 2021 Indonesia akan mengalami defisit anggaran Rancangan Anggaran Pendapatan Belanja Negara (RAPBN) kisaran 3,21\% - 4,17\% menurut Menteri Keuangan Sri Mulyani Indrawati. mengatakan melalui skema imbal dagang atau barter, diharapakan dapat mendukung pertumbuhan ekonomi nasional agar bisa semakin bergerak dan tumbuh [2], salah satunya dalam skema system barter komoditas ekspor hasil bumi antar negara [3].

Dimasa pandemik Covid-19 seperti sekarang ini banyak sekali pemberitaan dari media-media masa digital, masyarakat yang sudah tidak mampu memenuhi kebutuhan sehari hari dikarenakan kondisi keuangan yang tidak stabil sehingga perekonomian masyarakat mengalami penurunan drastis. Terlebih masyarakat kecil seperti pedagang, mengalami kerugian bahkan tidak dapat beroperasi lagi seperti; Ojek online, tukang becak, sopir angkutan umum, pekerja serabutan yang hanya mengandalkan pemasukan harian mengalami masa yang sangat sulit untuk bisa bertahan [4]. Bukan cuma masyarakat saja, banyak sektor-sektor usaha terkena dampak buruk dan kerugian secara pendapatan finansial dari fenomena virus Covid-19, dampak diantaranya adalah; terjadinya pemutusan Hubungan kerja (PHK) sebanyak 5.131 atau 35\% pekerja terkena PHK, sementara 19\% dirumahkan [5], dan terdapat 46 perusahaan besar bangkrut [6] serta menimbulkan dampak sosial yakni masyarakat kesulitan untuk memenuhi kebutuhan dasar hidup seperti memperoleh makanan, dimana warga miskin yang hanya mengandalkan pendapatan harian untuk memenuhi kebutuhan makanan. Hilangnya pendapatan bagi warga masyarakat berarti jumlah angka kemiskinan masyarakat akan semakin meningkat [4]. Sementara khusus untuk wilayah Nusa Tenggara Timur terdapat 219 orang di PHK, 4.852 orang dirumahkan, serta 1.458 dikurangi jam kerjanya [7], dan khususnya wilayah Kota Kupang sendiri terdapat 37 orang pekerja terkena PHK [8]. Dampak dari fenomena ini tentu saja menjadi perhatian serius dan kerugian finansial yang 
berkepanjangan serta kebutuhan sehari-hari yang harus terpenuhi, maka dari masalah yang terjadi perlu adanya inovasi alternatif yang dapat membantu masyarakat dalam mencukupi kebutuhan sehari-hari tanpa mengandalkan terlebih dahulu pengeluaran keuangan dengan penerapan transaksi barter barang ataupun kebutuhan pokok lainnya secara digital yang bisa menjadi alternatif bagi masyarakat dalam memenuhi kebutuhan hidupnya sehari hari.

Pengembangan sistem barter berbasis website ini dapat digunakan oleh siapa saja, baik masyarakat yang terdampak ekonomi pengaruh efek covid-19, masyarakat kalangan bawah sampai keatas dalam melakukan transaksi bertukar barang sesuai kebutuhan yang ada antara kedua belah pihak nantinya. Teknik Analisa kebutuhan menggunakan pengumpulan informasi dengan penyebaran kuesioner dan proses pengembangan perangkat lunak (design system) menggunakan pendekatan model Systems Development Life Cycle (SDLC) dimana terdapat 5 tahap yaitu; perencanaan, analisa, desain system, implementasi dan maintenance. dan pada penelitian ini hanya sampai pada proses desain system terlebih dahulu dan Analisa, agar melihat kebutuhan yang diinginkan pengguna.

Berdasarkan permasalahan yang ditemukan dan mengingat kesulitan masyarakat dalam memperoleh dan memenuhi kebutuhan sehari hari di masa pandemik Covid-19 sampai saat ini, maka peneliti memiliki gagasan untuk menganlisa terlebih dahulu dan mencoba merancang model sistem barter sebagai layanan alternatif transaksi barter barang dan konsumsi bahan makanan berbasis website dalam mencukupi kebutuhan sehari-hari dalam masa pandemik Covid-19 khususnya pada wilayah masyarakat NTT.

\section{A. Barter}

Sistem barter merupakan sebuah solusi kepada individu atau seseorang yang tidak mampu memproduksi segala kebutuhan hidup serta kebutuhan ekonomi dulunya sebelum mengenal uang, maka dulunya masyarakat sering menggunakan system barter dengan barang yang diinginkan.

Sistem barter sudah sangat jarang digunakan pada saat ini dikarenakan orang lebih senang menggunakan uang dalam kegiatan transaksinya. Ada beberapa kelemahan sistem barter sehingga ditinggalkan oleh orang.

Beberapa kelemahan atau kendala yang sering dialami sistem barter dalam melakukan transaksi atau pertukaran antara lain sebagai berikut:

1. Sulit menemukan orang yang mau menukarkan barangnya yang sesuai dengan kebutuhan yang diinginkan.

2. Sulit untuk menentukan nilai barang yang akan ditukarkan terhadap barang yang diinginkan.

3. Sulit menemukan orang yang mau menukarkan barangnya dengan jasa yang dimiliki atau sebaliknya.
4. Sulit untuk menemukan kebutuhan yang mau ditukarkan pada saat yang epat sesuai dengan keinginan. Artinya untuk memperoleh barang yang diinginkan memerlukan waktu yang relatif lama [1].

Berikut beberapa referensi penelitian tentang penerapan barter yang pernah diteliti sebelumnya, yaitu; sebuah Jurnal Ilmiah diteliti oleh Salmiati, dkk (2019) yang berjudul budaya barter dalam pusaran globalisasi pasar; studi kasus desa Labala, Nusa Tenggara Timur, yang mana dikatakan bahwa masyarakat di Desa Labala, Kabupaten Lembata, Provinsi Nusa Tenggara Timur, masih menggunakan sistem barter. Pasar barter tersebut menjadi wadah terjadinya interaksi sosial antara orang pesisir dengan orang pegunungan, [9]. Penelitian selanjutnya Nugroho dan Fadlilah (2015) yang berjudul Sistem Informasi Barter Online, menghasilkan sebuah layanan website sistem informasi barter online yang memudahkan admin untuk mengelola data barang, pengelolaan website (komentar, konfirmasi iklan, biaya dan data user). Sistem informasi barter ini sangat membantu dalam melakukan barter, dibuktikan dengan hasil kuesioner sebesar $80 \%$ menyatakan bahwa sistem informasi ini bermanfaat untuk melakukan barter [10]. Dan penelitian jurnal terakhir oleh Livia dan Halim (2017) tentang Sistem Informasi Penjualan dan Barter Barang Antik dan Koleksi, dimana bertujuan untuk membantu para kolektor menemukan barang-barang koleksi/antik yang mereka cari. Penjual akan memilih harga yang tepat dan sesuai dari beberapa penawaran pembeli untuk disepakati.Transaksi tersebut hanya dapat dilakukan dengan cara membayar menggunakan uang atau dengan cara barter, baik antara barang dengan barang ataupun barang dengan barang dan uang.[11]

Adapun perbedaan dengan penelitian yang diambil saat ini adalah, penelitian ini hanya akan mempermudah masyarakat melakukan barter dalam kota yang sama, tanpa menggunakan pengeluaran biaya, barang yang ditukar dapat melakukan proses negoisasi didalam system, dan system yang dikembangkan akan memiliki user interface yang bagus dan memliki konten bergambar yang lebih baik, mudah dan jelas dibandingkan penelitian sebelumya.

\section{B. Covid-19}

Coronavirus Disease 2019 (Covid-19) merupakan penyakit yang disebabkan oleh SARS Coronavirus 2 (SARSS-Cov-2). Pemberian nama penyakit ini dilakukan oleh WHO, sedangkan pemberian nama virus oleh International committee on Taxonomy of Viruses (ICTV). Covid-19 merupakan penyakit menular yang dapat menyerang tubuh manusia melalui kontak fisik atau melalui penyebaran melalui komunikasi tanpa mematuhi protocol Kesehatan atau yang belum dilakukab Vaksin. Dimana sampai saat ini hanya bisa dicegah dengan sistem imun tubuh manusia yang kuat dan sehat melalaui Vaksinisasi. 
Covid-19 dapat menular dan berkembang dengan cepat dan pesat kepada masyarakat yang belum menerima vaksinisasi. Namun untuk masyarakat yang memiliki sistem imun/kekebalan tubuh yang baik dan bagus, Covid-19 mampu dilawan dengan sistem imun yang ada didalam tubuh sendiri. Karena Covid-19 mampu terdeteksi jika telah dilakukan hasil test (Swab/Antigen/PCR).

Covid-19 neniliki 4 sebutan dalam mengidentifikasi atau menganalisis pasien, sebagai informasi pembagian jenis kelompok penderita oleh pihak kesehatan yaitu:

1. Orang dalam pemantauan (ODP)

2. Pasien dalam pengawasan (PDP)

3. Orang tanpa gejala (OTG)

4. Positif Covid-19

Covid-19 di Indonesia dilaporkan pertama kali dikaporkan pada tanggal 2 Maret 2020 sejumlah 2 kasus. Sementara itu data untuk Indonesia update hingga tanggal 20 April 2020 pukul 1630 WIB (infeksi emerging kemkes RI, 2020) adalah 6760 kasus konfirmasi, 590 kasus meninggal atau (8,7\%), 747 kasus sembuh $(11,1 \%), 5423$ kasus dalam perawatan $(80,2 \%)$. Covid 19 telah mengubah banyak kebiasaan yang telah berlangsung lama. Aktivitas pembelajaran dialihkan dengan menggunakan pembelajaran online dengan sistem e-learning, dan promosi usaha dengan sosial media dan smartphone. [12]

Nusa Tenggara Timur, kasus Covid-19 pertama kali dilaporkan pada tanggal 9 April 2020 sejumlah 1 kasus [13] dan terus meningkat seperti pada grafik penyebaran data Covid-19 di NTT berikut ini:

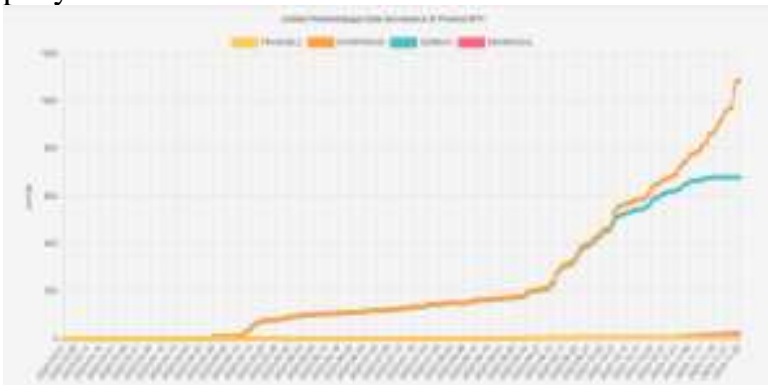

Gambar 1. Grafik peningkatan kasus Covid-19 di NTT [14]

C. Systems Development Life Cycle (SDLC)

Systems Development Life Cycle (SDLC) merupakan gambaran alur kerja kerangka perancangan sistem yang selalu bergerak seperti lingkaran roda, yang mmemiliki tahapan-tahapan alur kerja yaitu; investigate, analyze, design, implementation dan maintenance. Dalam langkah selanjutnya akan kembali pada tahap investigate jika dirasakan bahwa system yang ada sudah tidak efisien lagi untuk ditarapkan.

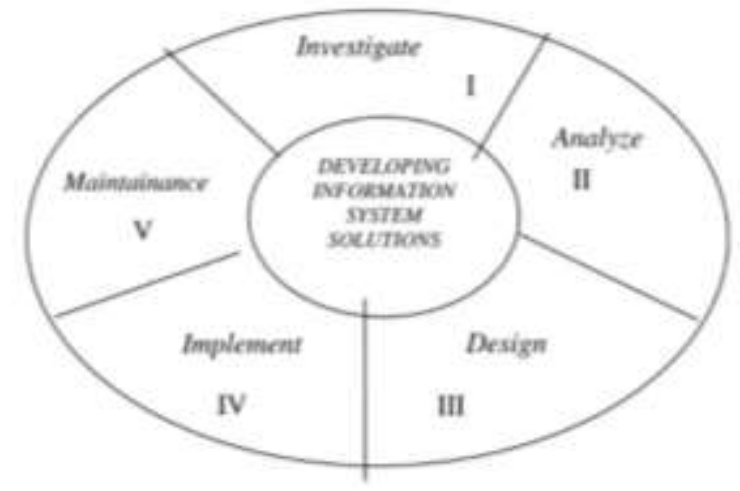

Gambar 2. Pola Perputaran Systems Development Life Cycle (SDLC)

1. Tahap perencanaan/investigation

Yaitu studi awal untuk membangun system baru dengan langkah-langkah sebagai berikut: (a) mendefinisikan masalah yang muncul dalam system, (b) mengidentifikasi kendala yang ada secara umum, (c) mengidentifikasi tujuan system yang dipenuhi, (d) membuat studi kelayakan, (e) mempersiapkan usulan penelitian sistem

2. Tahap analisis

Tahap analisis dapat diartikan suatu proses untuk memahami system yang ada dengan tujuan untuk merancang system baru atau diperbaharui.

3. Tahap perancangan/desain system

Mendesain system merupakan manfaat dalam memberikan gambaran atau model rancang bangun (blueprint) yang lengkap, sebagai pemahaman kepada programmer dalam membangun dan menyesuaikan model system nantinya.

4. Tahap penerapan

Penerapan merupakan kegiatan memperoleh dan mengidentifikasi sumber daya fisik dan konseptual untuk menghasilkan suatu system yang bekerja, dengan melakukan beberapa hal yaitu; merencanakan penerapan, mengumumkan penerapan, medapatkan sumber daya perangkat keras, mendapat sumber daya perangkat lunak, menyiapkan database, meyiapkan fasilitas fisik, training pengguna, dan masuk system baru.

5. Tahap pemeliharaan

Dalam penggunaan system dipandang perlu diadakan pemeliharaan system. Hal tersebut dikatahui atas beberapa alasan, antara lain: bermaksud untuk memperbaiki kesalahan, menjaga kemuktahiran system, dan meningkatkan system [15].

D. Pemodelan Berorientasi Objek Menggunakan Unified Modeling Language (UML)

UML merupakan bahasa yang sederhana dan grafis. UML memanfaatkan diagram untuk merepresentasikan model. Diagram-diagram yang dipakai dalam UML adalah diagram use case, class, sequence, transisi state, activity dan component. Ragam 
perangkat lunak computer menyediakan bisa dipakai untuk mengimplementasikan diagram-diagram UML [16].

\section{E. Skala Likert}

Skala likert seringkali digunakan untuk mengukur sikap, pendapat, dan persepsi seseorang atau sekelompok orang tentang fenomena sosial. Dengan skal likert, variable yang akan diukur dijabarkan menjadi indicator variable. Selanjutnya indicator tersebut dijadikan sebagai titik tolak untuk Menyusun item-item instrument yang dapat berupa pertanyaan [17].

Rumus dari skala likert adalah :

$\mathrm{T} \times \mathrm{Pn}$....

Keterangan :

$\mathrm{T}=$ Total jumlah responden yang memilih

Pn $=$ Pilihan angka skor likert

Skala likert dalam penelitian ini menggunakan 5 tingkatan untuk menyatakan sikap jawaban dari koresponden yaitu; (1) Sangat penting $=5$, (2) penting $=4$, (3) ragu-ragu $=3$, (4) tidak penting $=2$, dan (5) sangat tidak penting $=1$.

\section{METODE PENELITIAN}

Metode penelitian system barter ini memerlukan beberapa data dan pengembangan model system, agar menghasilkan sebuah layanan website yang diharapkan agar dapat menjawab kebutuhan pengguna nantinya.

1. Mengumpulkan Data

Pengumpulan data dimulai dengan mengumpulkan sumber-sumber literatur penelitian baik dari buku, jurnal ilmiah, berita-berita nasional dan memberikan kuesioner kepada koresponden melalui google form.

2. Mengolah Data

Pengolahan data selanjutnya adalah dengan menganalisa keinginan pengguna dalam pengembangan system yang akan dilakukan nantinya, dengan mengumpulkan data kuesioner dan diformulasikan melalui perhitungan Skala Likert.

3. Perancangan Sistem Barter Berbasis Web

Tahap ini akan dikembangkan model dari system barter yang sudah direncanakan dalam bentuk perancangan system.

4. Penerapan dan Pemeliharaan

Tahap ini akan dikembangkan system barter sesuai kebutuhan user dan kemudahan proses transaksi didalamnya, dan juga jika terjadi error atau perubahan system makan dapat dilakukan pemeliharaan atau maintenance untuk menghasilkan system yang lebih baik.

5. Hardware dan Software

Berikut spesifikasi perangkat keras dalam pengembangan website barter adalah sebagai berikut:
1) Laptop Asus ROG Hero III dengan Proseseor Intel(R) Core (TM) i7-8750H CPU @ $2.20 \mathrm{GHz}, 2.21 \mathrm{GHz}$

2) HDD 1 GB / SSD 300GB

3) Smartphone Oppo A92

Berikut daftar nama perangkat lunak dalam pengembangan perancangan sistem website barter saat ini dan nantinya, adalah sebagai berikut:

1) Sistem operasi windows 1064 bit

2) Google chrome untuk menjalankan web

3) Visual Studio Code

4) Xampp versi 3.2.4

\section{HASIL DAN PEMBAHASAN}

Hasil tingkat keinginan Sebagian masyarakat melalui kuesioner yang dikumpulkan dan di Analisa menggunakan Skala Likert mendapatkan antusias yang positif dan keinginan untuk dikembangkan system barter tersebut, maka system barter akan mulai dalam proses pemodelan rancangan system agar mudah di implementasikan nantinya dalam hasil website dan pengujian-pengujian unit nantinya:

\section{A. Soal Kuesioner}

Untuk mengumpulkan informasi minat masyarakat yang ingin dikembangkannya system barter, maka dibuatkan soal pertanyaan yang terlihat berikut ini :

1. P01: Apakah System barter barang (bertukar barang dengan barang lainnya) sangat penting di kembangkan sebagai sarana alternative pengganti nilai beli menggunakan Uang di era pendemik Covid-19?

2. P02: Apakah System barter barang sangat penting di kembangkan sebagai sarana pengganti nilai beli menggunakan Uang di era New Normal Juga?

3. P03: Pentingkah, jika barang yang ditukarkan harus bertemu secara langsung untuk dapat melihat kondisi dan keaslian barang yang ditukarkan kedua belah pihak?

4. P04: Pentingkah, jika pertukaran barang bisa melalui kota atau wilayah yang berbeda antara penukar? (namun akan beresiko dalam memastikan kondisi barang secara tidak langsung, dan mungkinkan ada biaya pengiriman barang yang dikeluarkan)

5. P05: Pentingkah, Jika nilai kedua barang yang ditukar memiliki nilai tukar yang sama atau selisih sedikit? (Contoh: beras 1KG harga Rp.6.000, ditukar dengan Gula pasir 1/2KG harga Rp.6.500)

6. P06: Pentingkah, jika system barter perlu dikembangkan melalui layanan website? sebagai media penghubung dan memberikan informasi barang-barang yang dapat ditemukan secara mudah antara pebarter?

7. P07: Pentingkah, jika system barter berbasis website dipermudah bentuk desain tampilannya dan proses kelola data informasi barternya oleh pengguna? 
8. P08: Pentingkah, untuk hak akses Admin (pengelola) website barter dapat memantau setiap konten barang yang diupload oleh pihak client (penukar/pengguna)?

9. P09: Pentingkah, untuk hak akses Admin (pengelola) website barter menon aktifkan akun client yang terindikasi mengupload konten barter yang berbahaya dan tidak sesuai dengan norma/etika (penukaran manusia, minuman keras, narkoba/narkotika, ketelanjangan manusia, senjata api, dll)?

10. P10: Pentingkah, website meminta dan menampilkan informasi pribadi pengguna dalam hal mengumpulkan informasi otentik dan keaslian pengguna saat mendaftarkan diri ke system website barter? (KTP, Foto Realtime dengan KTP, Foto diri, Nomor HP, Alamat Rumah, Nomor Rekening dll)

11. P11: Pentingkah, dalam sebuah website mencantumkan SYARAT dan KEBIJAKAN yang berlaku antara pihak penyedia (penanggung jawab website) layanan dan client (pengguna/pelaku barter)? untuk menyepakati apa saja yang menjadi prioritas dan non-priortias (diluar tanggung jawab penyedia layanan) yang akan melalui proses verifikasi persetujuan atau tidak disetujui oleh client terlebih dahulu.

12. P12: Pentingkah, dalam sebuah website membuat halaman pengaduan atau melapor jika client ingin bertanya atau melaporkan sesuatu terkait layanan yang ada?

Dari pertanyaan diatas kepada responden, maka telah didapat 79 jumlah data yang telah diterima, untuk di akumulasi menggunakan Skala Likert. Perhatikan tabel 1 berikut ini:

Tabel 1. Total pilihan jawaban dari koresponden

\begin{tabular}{|c|c|c|c|c|c|}
\hline \multirow{3}{*}{ Pertanyaan } & \multicolumn{5}{|c|}{ TOTAL PILIHAN RESPONDEN } \\
\cline { 2 - 6 } & $\begin{array}{c}\text { Sangat } \\
\text { Penting }\end{array}$ & Penting & $\begin{array}{c}\text { Ragu- } \\
\text { ragu }\end{array}$ & $\begin{array}{c}\text { Tidak } \\
\text { Penting }\end{array}$ & $\begin{array}{c}\text { Sangat Tidak } \\
\text { Penting }\end{array}$ \\
\hline P01 & 32 & 33 & 7 & 6 & 1 \\
\hline P02 & 26 & 35 & 13 & 5 & 0 \\
\hline P03 & 50 & 26 & 3 & 0 & 0 \\
\hline P04 & 17 & 24 & 26 & 10 & 2 \\
\hline P05 & 27 & 34 & 12 & 6 & 0 \\
\hline P06 & 30 & 43 & 6 & 0 & 0 \\
\hline P07 & 39 & 38 & 2 & 0 & 0 \\
\hline P08 & 44 & 29 & 4 & 2 & 0 \\
\hline P09 & 52 & 23 & 3 & 1 & 0 \\
\hline P10 & 39 & 27 & 10 & 2 & 1 \\
\hline P11 & 46 & 31 & 2 & 0 & 0 \\
\hline P12 & 46 & 31 & 1 & 1 & 0 \\
\hline & & & & & \\
\hline
\end{tabular}

Dari tabel 1 sebelumnya, kemudian diberikan bobot nilai pada masing-masing 5 jenis jawaban (sangat penting (5), penting (4), ragu-ragu (3), tidak penting (2), dan sangat tidak penting(1)) dan dikalikan dengan setiap jumlah pertanyaan (ada 12 pertanyaan),
Tabel 2. Jumlah Total Skor

\begin{tabular}{|c|c|c|c|c|c|c|}
\hline \multirow{3}{*}{ Pertanyaan } & \multicolumn{5}{|c|}{ TOTAL BOBOT PILIHAN RESPONDEN } & \multirow{2}{*}{ Total } \\
\cline { 2 - 6 } & $\begin{array}{c}\text { Sangat } \\
\text { Penting }\end{array}$ & Penting & $\begin{array}{c}\text { Ragu } \\
\text {-ragu }\end{array}$ & $\begin{array}{c}\text { Tidak } \\
\text { Pentin } \\
\text { g }\end{array}$ & $\begin{array}{c}\text { Sangat } \\
\text { Tidak } \\
\text { Penting }\end{array}$ & \\
\hline P01 & 160 & 132 & 21 & 12 & 1 & $\mathbf{3 2 6}$ \\
\hline P02 & 130 & 140 & 39 & 10 & 0 & $\mathbf{3 1 9}$ \\
\hline P03 & 250 & 104 & 9 & 0 & 0 & $\mathbf{3 6 3}$ \\
\hline P04 & 85 & 96 & 78 & 20 & 2 & $\mathbf{2 8 1}$ \\
\hline P05 & 135 & 136 & 36 & 12 & 0 & $\mathbf{3 1 9}$ \\
\hline P06 & 150 & 172 & 18 & 0 & 0 & $\mathbf{3 4 0}$ \\
\hline P07 & 195 & 152 & 6 & 0 & 0 & $\mathbf{3 5 3}$ \\
\hline P08 & 220 & 116 & 12 & 4 & 0 & $\mathbf{3 5 2}$ \\
\hline P09 & 260 & 92 & 9 & 2 & 0 & $\mathbf{3 6 3}$ \\
\hline P10 & 195 & 108 & 30 & 4 & 1 & $\mathbf{3 3 8}$ \\
\hline P11 & 230 & 124 & 6 & 0 & 0 & $\mathbf{3 6 0}$ \\
\hline P12 & 230 & 124 & 3 & 2 & 0 & $\mathbf{3 5 9}$ \\
\hline
\end{tabular}

Hasil pada tabel 2 diatas didapatkan total skor dari setiap 12 pertanyaan masing-masing yang telah diberikan bobot penilaian, yaitu; $\mathrm{P} 01=326, \mathrm{P} 02=319$, $\mathrm{P} 03=363, \mathrm{P} 04=281, \mathrm{P} 05=319, \mathrm{P} 06=340, \mathrm{P} 07=$ $353, \mathrm{P} 08=352, \mathrm{P} 09=363, \mathrm{P} 10=338, \mathrm{P} 11=360$, dan $\mathrm{P} 12=359$.

Kemudian untuk menentukan interpretasi skor tertinggi dan skor terendah. Untuk menentukan skor maksimun/tertinggi, maka rumusnya adalah jumlah responden $\mathrm{x}$ skor tertinggi. Sedangkan untuk skor minimun/terendah digunakan rumus jumlah responden $\mathrm{x}$ skor terendah, dan akan mengetahui interval penilaian:

$$
\begin{array}{ll}
\text { Skor maksimum } & =79 \times 5=395 \\
\text { Skor minimum } & =79 \times 1=79
\end{array}
$$

Untuk mengetahui rumus intervalnya (jarak) dan interpretasi persen agar mengetahui penilaian dengan metode untuk mencari interval skor persen, maka perlu dirumuskan lagi cara perhitungannya, yaitu:

Interval (I) $=100 /$ Jumlah Skor.

Maka; 100 / $5=20$, maka hasil interval (I) adalah 20, dimana ini merupakan interval dari jarak terendah $0 \%$ sampai pada jarak tertinggi 100\%. Berikut interpretasi skor berdasarkan intervalnya:

1. Angka $0 \%-19,99 \%=$ Sangat Tidak Penting

2. Angka $20 \%-39,99 \%=$ Tidak Penting

3. Angka $40 \%-59,99 \%=$ Ragu-ragu

4. Angka $60 \%-79,99 \%=$ Penting

5. Angka $80 \%-100 \%=$ Sangat Penting

Tahap terakhir adalah menghitung presentase $(\%)$ dimana menjadi tahap akhir untuk mengetahui indeks. Rumus persentasnya adalah:

Total skor / Total skor maksimum x 100 .

Maka dapat dihasilkan dalam tabel 4 berikut ini dari hasil perhitungannya: 
Tabel 3. Hasil Persentase (\%)

\begin{tabular}{|c|c|c|c|}
\hline Pertanyaan & $\begin{array}{c}\text { Total } \\
\text { Skor }\end{array}$ & $\begin{array}{c}\text { Total Skor } \\
\text { Maksimum }\end{array}$ & Persentase (\%) \\
\hline P01 & 326 & 395 & 82.53 \\
\hline P02 & 319 & 395 & 80.76 \\
\hline P03 & 363 & 395 & 91.90 \\
\hline P04 & 281 & 395 & 71.14 \\
\hline P05 & 319 & 395 & 80.76 \\
\hline P06 & 340 & 395 & 86.08 \\
\hline P07 & 353 & 395 & 89.37 \\
\hline P08 & 352 & 395 & 89.11 \\
\hline P09 & 363 & 395 & 91.90 \\
\hline P10 & 338 & 395 & 85.57 \\
\hline P11 & 360 & 395 & 91.14 \\
\hline P12 & 359 & 395 & 90.89 \\
\hline
\end{tabular}

\section{B. Perancangan Sistem Barter Berbasis WEB}

Dalam pengembangan perancangan barter ini menggunakan model UML sehingga mengetahui kebutuhan, model, hak akses dan alur kerja system nantinya.

\section{Use Case Diagram}

Perancangan use case diagram merupakan hubungan antara actor dengan system atau yang dapat mengakses menu-menu didalam sebuah system. Berikut interaksi actor dan menu didalam sebuah system barter dimana terdapat 3 aktor yaitu Admin, Pemilik dan Penukar.

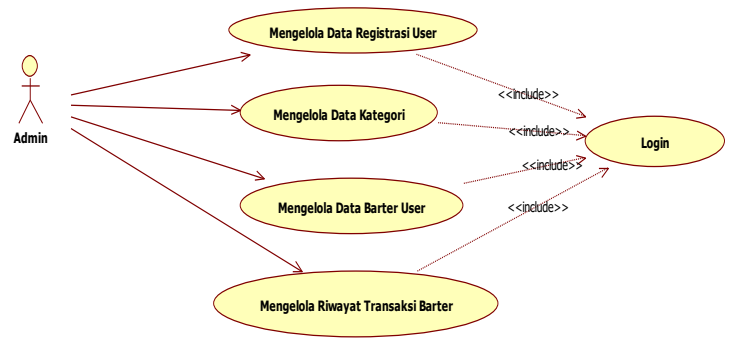

Gambar 3. Use Case Diagram Admin

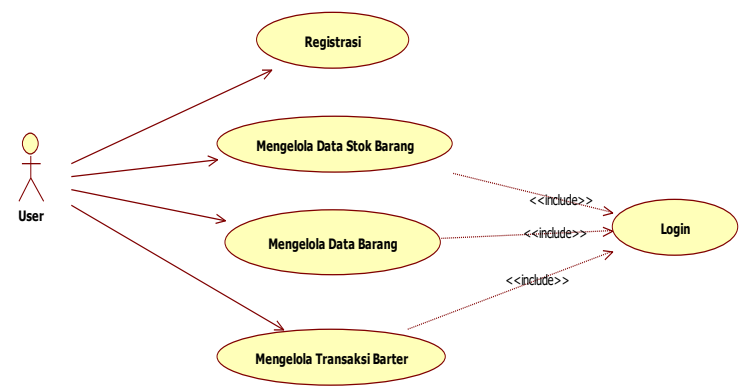

Gambar 4. Use Case Diagram Pemilik

\section{Activity Diagram}

Activity diagram berikut akan menjelaskan tahap dan proses setiap actor dalam berkomunikasi pada alur kerja berdasarkan use case.

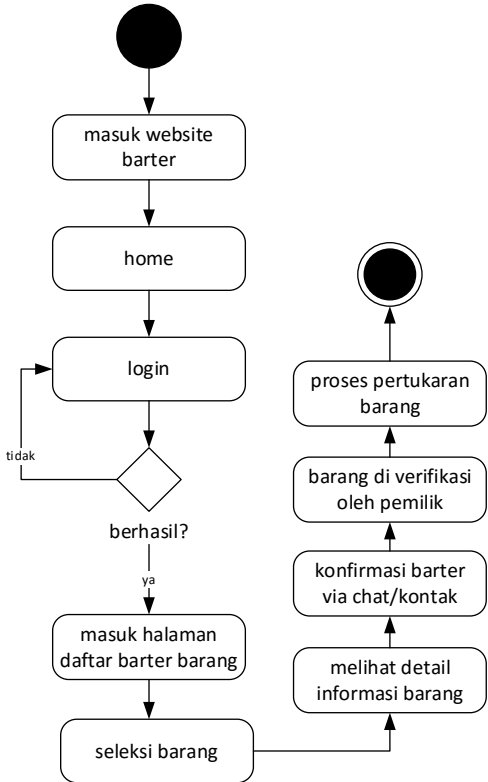

Gambar 5. Activity Diagram user (pemilik)

Pada gambar 5, merupakan gambaran alur setiap langkah bagi actor penukar dalam melakukan transaksi barter sampai pada bertemu dengan pemilik barang.

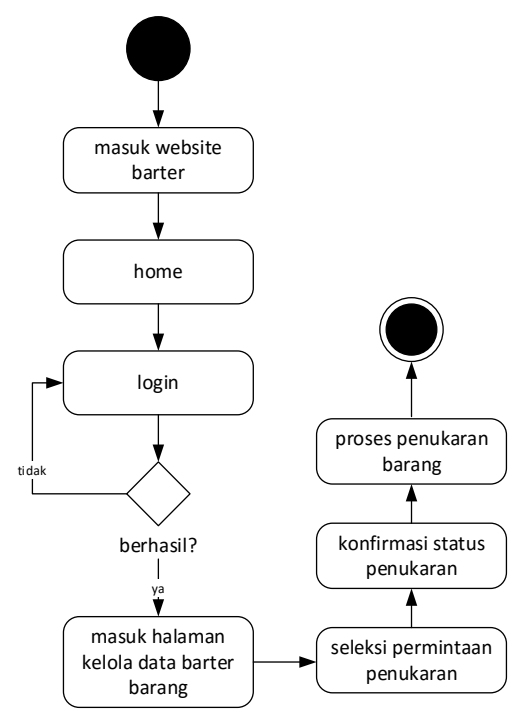

Gambar 6. Activity Diagram user Melakukan Konfirmasi Pertukaran Barang

Pada gambar 6 menunjukkan proses pemilik melakukan konfirmasi status pertukaran (barter) barang dengan penukar barang. 


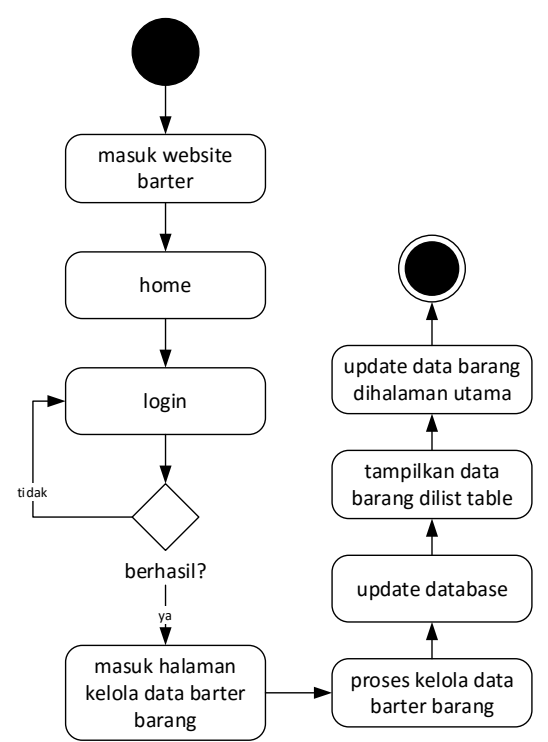

Gambar 7. Activity Diagram user Melakukan Kelola Data Barter Barang

Pada gambar 7 menunjukkan pemilik melakukan proses kelola data barter barang (save. edit. deleted dan search).

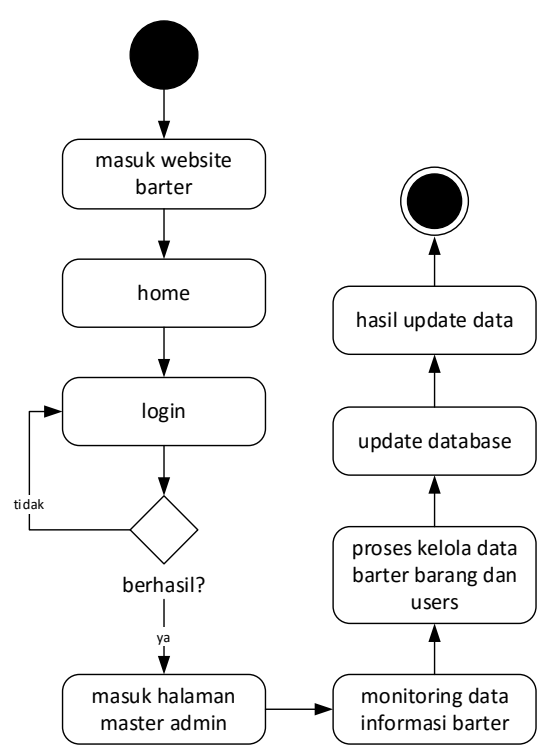

Gambar 8. Activity Diagram Admin Melakukan Kelola Data System Barter

Pada gambar 8 menunjukkan admin melakukan proses kelola dan memonitoring data informasi data barter dan akun users (save. edit. deleted dan search).

\section{Squensial Diagram}

Sequensial diagram system barter menggambarkan bagaimana sebuah operasi dapat tersampaikan dan pesan apa saja yang dikirimkan kedalam interaksi sebuah system.

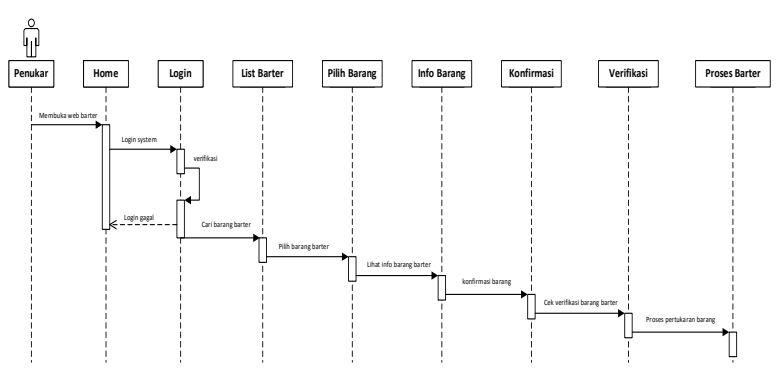

Gambar 9. Squensial Diagram Penukar

Dari gambar 9 di atas penukar masuk kehalaman website barter, kemudian lakukan login, setelah login berhasil makan penukar bisa mencari daftar barang yang ingin dibarter, jika ditemukan yang cocok kemudian dipilih dan bisa melihat informasi detail dari barang yang ingin ditukar, kemudian lakukan konfirmasi barang yang dipilih tunggu sampai pemeilik barang lakukan konfirmasi balik dan penukar dapat melihat secara langsung barang yang ingin ditukar, jika diterima maka penukar dan pemilik barang bisa melakukan proses barter secara langsung.

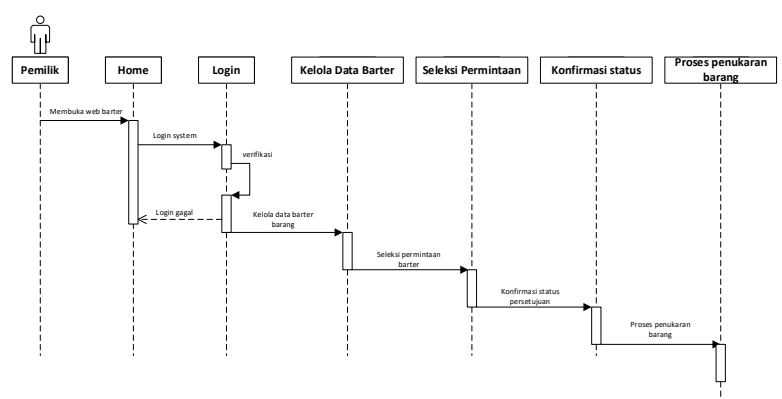

Gambar 10. Squensial Diagram Pemilik Konfirmasi Pertukaran Barang

Dari gambar 10 di atas pemilik masuk kehalaman website barter, kemudian lakukan login, setelah login berhasil makan pemilik bisa melakukan seleksi data permintaan barter dari penukar, jika cocok sesuai permintaan makan bisa dilakukan konfirmasi status distujui dan proses penukaran barang bisa dilakukan secara langsung.

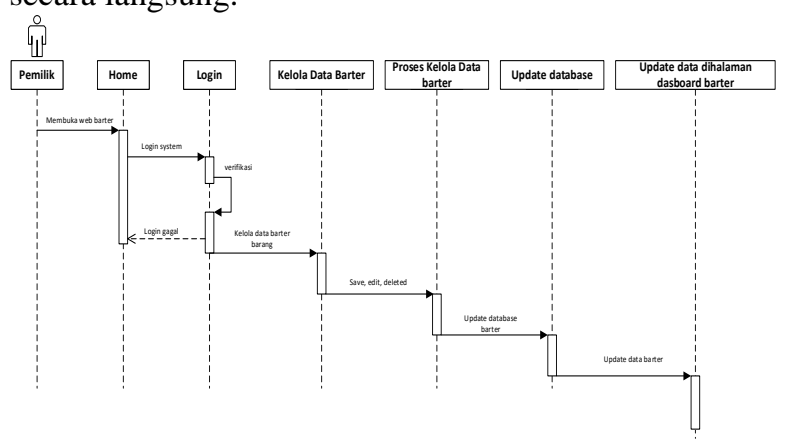

Gambar 11. Squensial Diagram Pemilik Kelola Barter Barang

Dari gambar 11, pemilik masuk kehalaman website barter, kemudian lakukan login, setelah login berhasil makan pemilik bisa melakukan kelola data barter 
barang yang ada dihalaman pemilik, data yang sudah dikelola (save, edit, deleted) langsung terupdate pada database dan halaman list data barter.

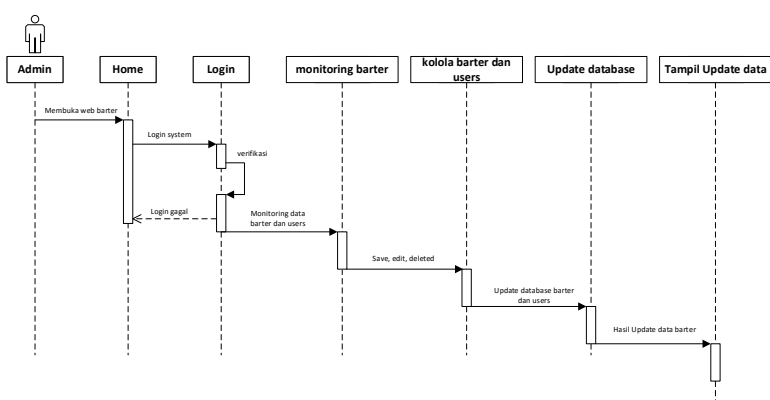

Gambar 12. Squensial Diagram Admin Kelola Barter Barang dan users

Dari gambar 12, admin masuk kehalaman website barter, kemudian lakukan login, setelah login berhasil makan admin bisa melakukan kelola data barter barang dan users yang ada dihalaman admin, data yang sudah dikelola (save, edit, deleted) langsung terupdate pada database dan halaman list data barter dan users.

\section{Class Diagram}

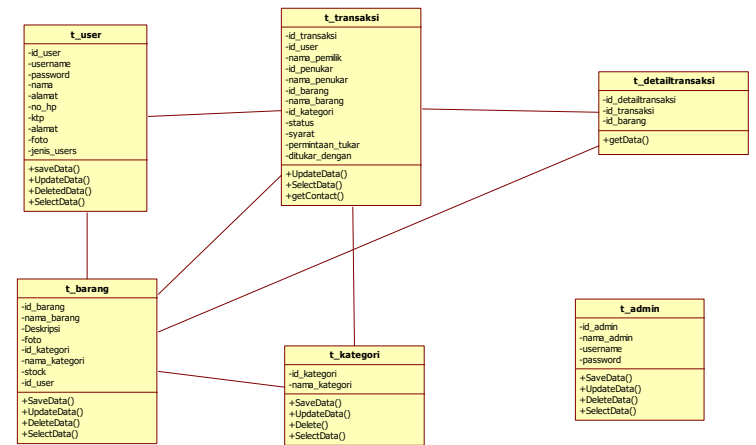

Gambar 13. Class Diagram

\section{Pengujian Sistem (BlackBox)}

Pengujian blackbox ini dilakukan untuk mengetahui pengujian fungionalitas perangkat lunak, tanpa harus mengetahui internal code dadalam website barter yang dikembangkan.

Tabel 4. Pengujian Sistem

\begin{tabular}{|c|c|c|c|}
\hline No & $\begin{array}{c}\text { Nama } \\
\text { Pengujian }\end{array}$ & $\begin{array}{l}\text { Kondisi } \\
\text { Pengujian }\end{array}$ & Hasil Pengujian \\
\hline \multirow[t]{2}{*}{1} & \multirow[t]{2}{*}{$\begin{array}{l}\text { Form } \\
\text { Login } \\
\text { Admin }\end{array}$} & $\begin{array}{l}\text { 1. Jika } \\
\text { username dan } \\
\text { password } \\
\text { tidak diisi, } \\
\text { dan user } \\
\text { langsung } \\
\text { mengklik } \\
\text { tombol barter. }\end{array}$ & $\begin{array}{l}\text { 1. Muncul pesan } \\
\text { kesalahan "username } \\
\text { dan password belum } \\
\text { diinput" }\end{array}$ \\
\hline & & $\begin{array}{l}\text { 2. Jika } \\
\text { username dan } \\
\text { password } \\
\text { diisi tetap } \\
\text { salah }\end{array}$ & $\begin{array}{l}\text { 2. Muncul pesan } \\
\text { "usernamelpassword } \\
\text { salah" }\end{array}$ \\
\hline
\end{tabular}

\begin{tabular}{|c|c|c|c|}
\hline No & $\begin{array}{c}\text { Nama } \\
\text { Pengujian }\end{array}$ & $\begin{array}{l}\text { Kondisi } \\
\text { Pengujian }\end{array}$ & Hasil Pengujian \\
\hline 2 & $\begin{array}{l}\text { Form Data } \\
\text { List User } \\
\text { (Admin) }\end{array}$ & $\begin{array}{l}\text { Admin } \\
\text { membuka } \\
\text { halaman list } \\
\text { users yang } \\
\text { terdaftar }\end{array}$ & $\begin{array}{l}\text { Menampilkan daftar } \\
\text { list } \text { users didalam table } \\
\text { gridview. }\end{array}$ \\
\hline 3 & $\begin{array}{l}\text { Form Data } \\
\text { List } \\
\text { Transaksi } \\
\text { Barter } \\
\text { (Admin) }\end{array}$ & $\begin{array}{l}\text { Jika terdapat } \\
\text { jenis barang } \\
\text { yang dibater } \\
\text { tidak sesuai dan } \\
\text { melanggar } \\
\text { peraturan UU } \\
\text { (miras, narkoba, } \\
\text { penjualan } \\
\text { manusia dll) }\end{array}$ & $\begin{array}{l}\text { Admin menghapus } \\
\text { konten milik penukar, } \\
\text { dan melaporkan } \\
\text { kepihak berwajib. }\end{array}$ \\
\hline \multirow[t]{2}{*}{4} & \multirow{2}{*}{$\begin{array}{l}\text { Form } \\
\text { Login User } \\
\text { (Pemilik } \\
\text { dan } \\
\text { Penukar) }\end{array}$} & $\begin{array}{l}\text { 1. Jika } \\
\text { username dan } \\
\text { password } \\
\text { tidak diisi, } \\
\text { dan user } \\
\text { langsung } \\
\text { mengklik } \\
\text { tombol } \\
\text { barter. }\end{array}$ & $\begin{array}{l}\text { 1. Muncul pesan } \\
\text { kesalahan "username } \\
\text { dan password belum } \\
\text { diinput" }\end{array}$ \\
\hline & & $\begin{array}{l}\text { 2. Jika } \\
\text { username } \\
\text { dan } \\
\text { password } \\
\text { diisi tetap } \\
\text { salah } \\
\end{array}$ & $\begin{array}{l}\text { 2. Muncul pesan } \\
\text { "usernamelpassword } \\
\text { salah" }\end{array}$ \\
\hline 5 & $\begin{array}{l}\text { Form } \\
\text { Register } \\
\text { User } \\
\text { (Pemilik } \\
\text { dan } \\
\text { Penukar) } \\
\end{array}$ & $\begin{array}{l}\text { Jika salah satu } \\
\text { isian tidak terisi }\end{array}$ & $\begin{array}{l}\text { Muncul pesan "data } \\
\text { masih kosong" }\end{array}$ \\
\hline \multirow[t]{3}{*}{6} & \multirow{3}{*}{$\begin{array}{l}\text { Form } \\
\text { Kelola data } \\
\text { barter }\end{array}$} & $\begin{array}{l}\text { 1. Pada kolom } \\
\text { isian barter } \\
\text { salah satu } \\
\text { data tidak } \\
\text { diinput dan } \\
\text { langsung } \\
\text { mengklik } \\
\text { tombol } \\
\text { simpan } \\
\end{array}$ & $\begin{array}{l}\text { 1. Muncul pesan "data } \\
\text { masih kosong" }\end{array}$ \\
\hline & & $\begin{array}{l}\text { 2. Pada kolom } \\
\text { isian barter } \\
\text { telah mengisi } \\
\text { semua data } \\
\text { dan } \\
\text { mengklik } \\
\text { tombol } \\
\text { simpan } \\
\end{array}$ & $\begin{array}{l}\text { 2. Muncul pesan "data } \\
\text { berhasil disimpan" }\end{array}$ \\
\hline & & $\begin{array}{ll}\text { 3. } & \text { Pada } \\
\text { gridview } \\
\text { users } \\
\text { mengklik } \\
\text { tombol } \\
\text { hapus data } \\
\text { barter } \\
\end{array}$ & $\begin{array}{l}\text { 3. Muncul pesan "data } \\
\text { berhasil dihapus" }\end{array}$ \\
\hline \multirow[t]{2}{*}{7} & \multirow[t]{2}{*}{$\begin{array}{l}\text { Form } \\
\text { Transaksi } \\
\text { barter }\end{array}$} & $\begin{array}{ll}\text { 1. } & \text { Penukar } \\
\text { memilik } \\
\text { salah satu } \\
\text { item barter }\end{array}$ & $\begin{array}{l}\text { 1. Akan muncul form } \\
\text { detail produk barter, } \\
\text { dan penukar dapat } \\
\text { langsung melakukan } \\
\text { komunikasi dengan } \\
\text { pemilik barang } \\
\text { barter } \\
\end{array}$ \\
\hline & & 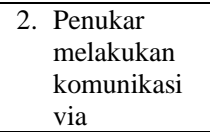 & $\begin{array}{l}\text { 2. Sistem akan } \\
\text { langsung mendirect } \\
\text { kehalaman WA } \\
\text { pemilik secara }\end{array}$ \\
\hline
\end{tabular}




\begin{tabular}{|l|l|l|l|}
\hline No & $\begin{array}{c}\text { Nama } \\
\text { Pengujian }\end{array}$ & $\begin{array}{l}\text { Kondisi } \\
\text { Pengujian }\end{array}$ & Hasil Pengujian \\
\hline & & WA/SMS & langsung untuk \\
& & dengan & berkomunikasi, dan \\
& pemilik & jika mengklik via \\
& barang barter & SMS makan akan \\
& melalui & menampilkan \\
& tombol & halaman kontak \\
& komunikasi & Pemilik untuk \\
& di website & melakukan \\
& & komunikasi via \\
& & SMS/telp \\
\hline
\end{tabular}

D. Implementasi Pada Aplikasi Berbasis WEB

Hasil implementasi dari alur proses kerangka diagram system diatas dapat dibentuk dalam model implementasi system barter yang dikembangkan sebagai berikut.

1. Tampilan menu login admin

Menu ini merupakan menu tampilan login untuk admin, agar dapat masuk kehalaman dashboard admin untuk mengelola dan memonitoring data barter dan users.

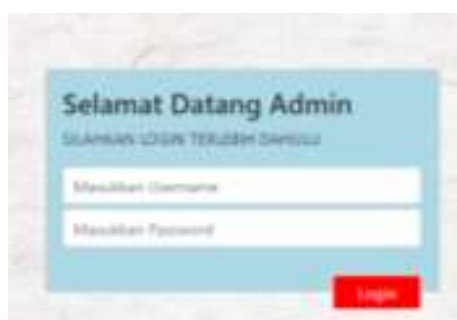

Gambar 14. Tampilan form login admin

2. Tampilan data users (admin)

Halaman ini bertujuan untuk seorang admin bisa melakukan konfirmasi dan memantau data users yang terdaftar.

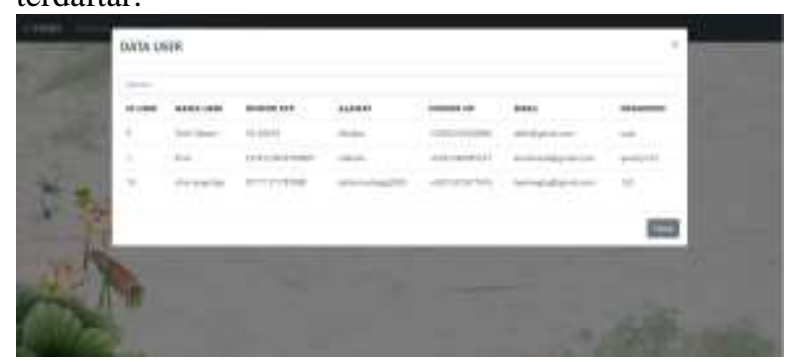

Gambar 15. Tampilan form data users (admin)

3. Tampilan kategori (Admin)

Halaman ini bertujuan untuk seorang admin bisa menginput data kategori/jenis barang barter.

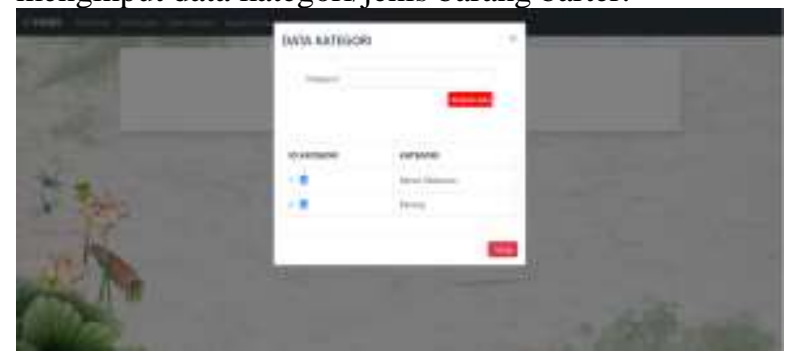

Gambar 16. Tampilan form kategori (admin)
4. Tampilan aktifitas barter users (admin)

Halaman ini bertujuan untuk seorang admin bisa memantau transaksi barter users.

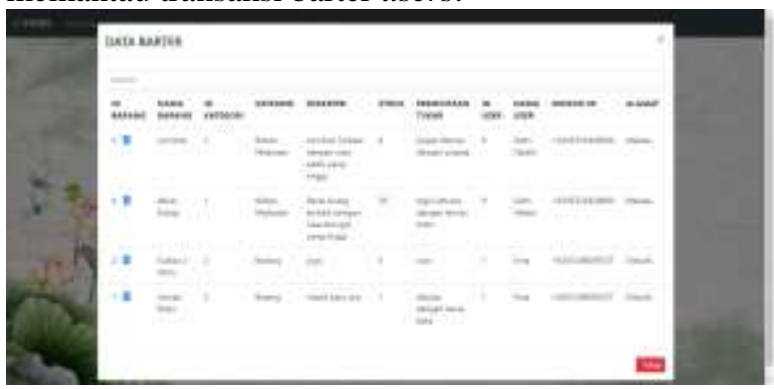

Gambar 17. Tampilan form aktifitas barter user

$$
\text { (admin) }
$$

\section{Tampilan halaman login (users)}

Halaman ini bertujuan seorang user dapat login dan masuk ke halaman dashboard master halaman kelola data barter (pemilik/penukar).

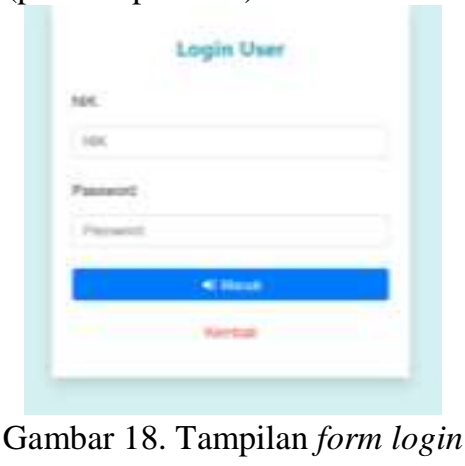

6. Tampilan halaman register user

Halaman ini bertujuan seorang user dapat melakukan register terlebih dahulu jika belum memiliki akun, agar bisa login dan masuk ke halaman dashboard master user (pemilik/penukar).

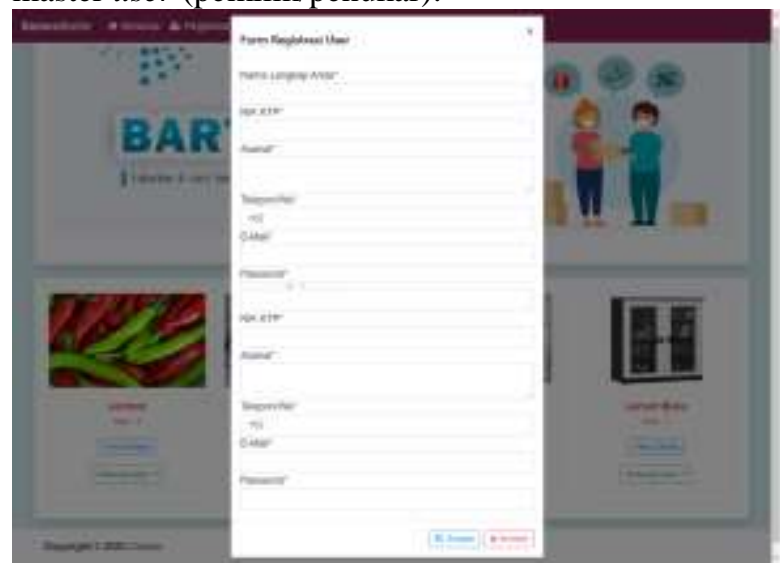

Gambar 19. Tampilan form register (pemilik)

7. Perancangan halaman kelola users

Halaman ini bertujuan seorang pemilik dapat mengedit informasi pribadinya kembali jika ada perubahan. 


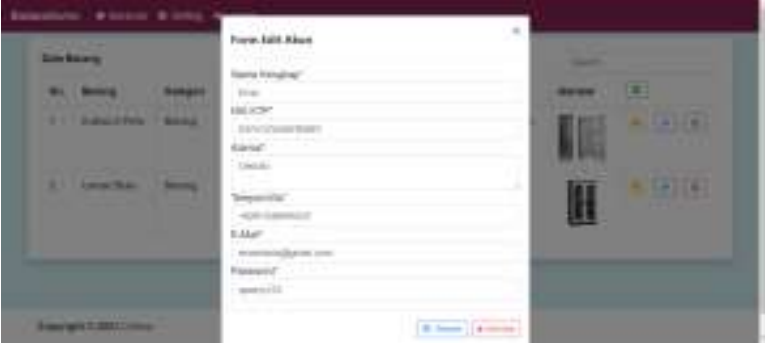

Gambar 20. Tampilan form kelola users

8. Tampilan halaman barang barter user

Halaman ini bertujuan seorang pemilik dapat mengelola (save, edit dan deleted) data barang yang akan dibarterkan ke masyarakat.

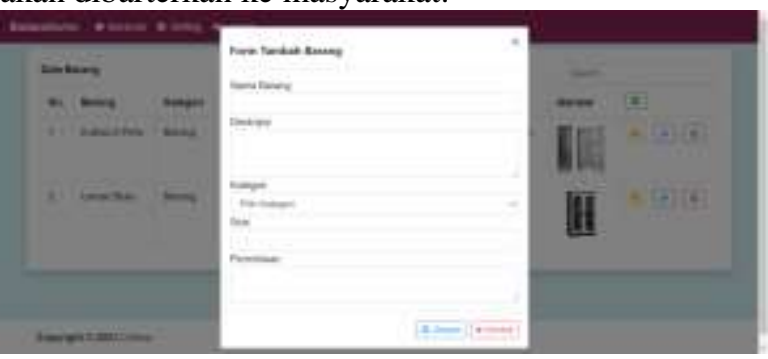

Gambar 22. Tampilan form barang barter user

9. Tampilan halaman utama barter

Halaman ini adalah halaman awal saat website barter dibuka, akan menampilkan informasi produkproduk yang dibarterkan.

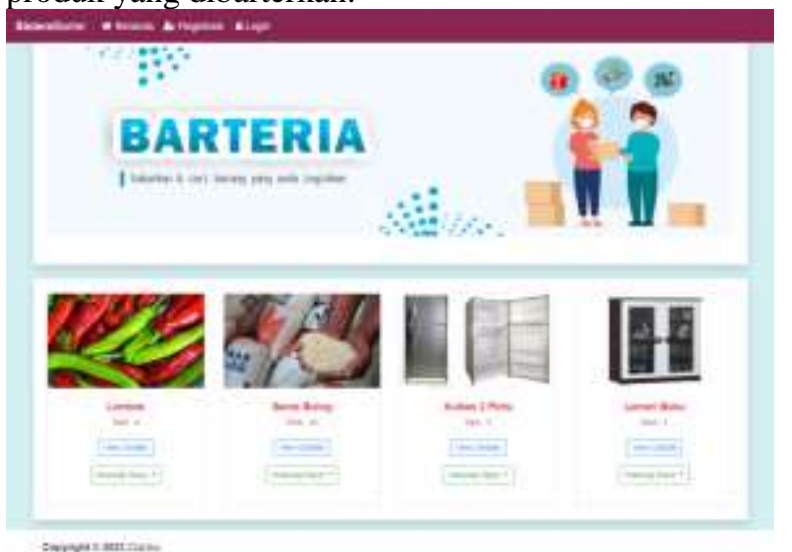

Gambar 26. Tampilan form utama (penukar)

10. Tampilan halaman detail dan kontak transaksi barter (penukar dan pemilik)

Halaman ini adalah halaman untuk para penukar barang bisa melihat lebih detail barang yang ingin dibarterkan dengan imbalan barang yang diinginkan, serta dapat mengubungi langsung pemilik untuk melakukan transaksi secara langsung.

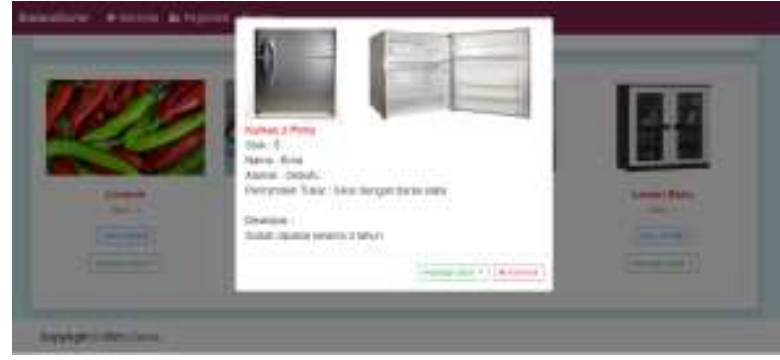

Gambar 28. Tampilan form detail dan kontak transaksi barter (penukar dan pemilik)

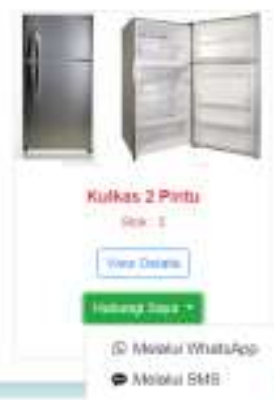

Gambar 29. Tampilan form kontak transaksi barter (penukar dan pemilik)

11. Tampilan halaman ketentuan dan syarat user

Halaman ini adalah halaman untuk para penukar barang agar bisa membaca ketentuan dan syarat antara pengelola website, penukar dan pemilik barang barter, agar menyepakati dan memenuhi transaksi dan data yang ada didalam system.

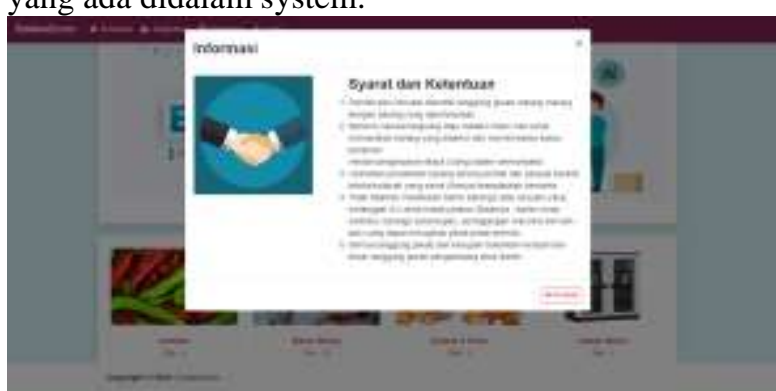

Gambar 30. Tampilan form ketentuan dan syarat user

\section{KESIMPULAN}

Berdasarkan hasil penelitian melalui tahap analisa kebutuhan, rancangan system, dan pengujian website barter berbasis website, maka dapat diambil kesimpulan yaitu; tingkat keinginan sebagian masyarakat sangat antusias dengan dikembangkannya system barter, terlihat dari rata-rata presentase nilai maksimalnya yang dihitung dengan rumus Skala Likert adalah 85,93\% yaitu "Sangat Penting" jika website ini dikembangkan untuk digunakan nantinya, sebagai media alternatif untuk membantu masyarakat dalam bertukar barang yang dibutuhkan sebagai upaya bentuk memenuhi dan mencukupi kebutuhan rumah tangga di masa pandemik Covid-19. 


\section{DAFTAR PUSTAKA}

[1] I. Atarina and A. Hapsila, Manajemen Perbankan, Yogyakarta: Deepublish, 2015.

[2] M. J. Nussah, "Barter Model Atasi Deficit RAPBN 2021 Ekonomi Nasional," 20 Juli 2020. [Online]. Available: http://koranbogor.com/berita/politik/bartermodel-atasi-defisit-rapbn-2021-ekonominasional/.

[3] Sulaeman, "Imbas Corona, Pemerintah Genjot Sistem Barter Komoditas Ekspor Hasil Bumi Indonesia," Merdeka, 16 Juni 2020. [Online]. Available:

https://www.merdeka.com/uang/imbas-coronapemerintah-genjot-sistem-barter-komoditasekspor-hasil-bumi-indonesia.html. [Accessed 03 Mei 2021].

[4] F. Pratama, "Solusi Jitu hadapi Dampak Sosial Virus Corona (covid-19)," 424 2020. [Online]. Available: https://puspensos.kemsos.go.id/solusi-jituhadapi-dampak-sosial-virus-corona-covid-19.

[5] F. Prayoga, "35\% Pekerja Indonesia Kena PHK akibat Covid-19," 07 Oktober 2020. [Online]. Available: https://economy.okezone.com/read/2020/10/07/ 320/2289946/35-pekerja-indonesia-kena-phkakibat-covid-19.

[6] A. D. Afriyadi, "Tembus Rekor! 46 Perusahaan Raksasa Bangkrut Gara-gara Corona," 23 Agustus 2020. [Online]. Available: https://finance.detik.com/berita-ekonomibisnis/d-5143179/tembus-rekor-46-perusahaanraksasa-bangkrut-gara-gara-corona.

[7] B. Tokan, "219 tenaga kerja NTT terkena PHK dampak pandemi COVID-19," 04 Mei 2020. [Online]. Available: https://www.antaranews.com/berita/1463901/21 9-tenaga-kerja-ntt-terkena-phk-dampakpandemi-covid-19\#mobile-src.

[8] RNC, "Di Kota Kupang, 957 Pekerja Terdampak Covid-19, 37 Orang Terken PHK," 30 April 2020. [Online]. Available: https://rakyatntt.com/di-kota-kupang-957pekerja-terdampak-covid-19-37-orang-kenaphk/.
[9] S. A. Rahman and R. , "Budaya barter dalam pusaran globalisasi pasar: Kasus desa Labala, Nusa Tenggara Timur," Jurnal Kebudayaan, vol. 14, no. 2, p. 115, 2122019.

[10] D. A. Nugroho and U. Fadlilah, "Sistem informasi barter online," Fakultas Komunikasi dan Informatika Universitas Muhammadiyah Surakarta, Surakarta, 2015.

[11] L. E. Gunawan and H. B. Santoso, "Sistem Informasi Penjualan Dan Barter Barang Antik dan Koleksi," Jurnal Informatika dan Sistem Informasi (JUISI), vol. III, no. 1, pp. 32-41, 2017.

[12] N. L. Abdullah, . T. j. Simarmata, D. O. Sulaiman and C. Prianto, Pandemik Covid19; Persoalan dan relfeksi di Indonesia, T. Limbong, Ed., Yayasan Kita Menulis, 2020.

[13] S. M. Bere, "Buka Media Sosial, Pasien Positif Corona Pertama di NTT: Ini Membuat Saya Semakin Tertekan," 1304 2020. [Online]. Available:

https://kupang.kompas.com/read/2020/04/13/09 424741/buka-media-sosial-pasien-positifcorona-pertama-di-ntt-ini-membuatsaya page $=$ all.

[14] Gugus Tugas Percepatan Penanganan COVID19 NTT, "Sebaran Data," 26 November 2020. [Online]. Available: http://www.covid19.nttprov.go.id/home/data.

[15] R. McLeod, Management Information Systems, New Jersey (USA): Pearson/Prentice Hall, 2010.

[16] H. Purnomo, Pemodelan dan Simulasi untuk Pengelolaan Adaptif Sumber Daya Alam dan Lingkungan, Bogor: IPB Press, 2019.

[17] Sugiyono, Metode Penelitian Pendidikan Pendekatan Kuantitatif, Kualitatif, dan R\&D, Bandung: Alfabeta, 2014. 